\title{
ORGANIZATION OF TRAINING B Y COOPERATION / COMPETITION METHOD IN FOREIGN LANGUAGE CLASSES
}

\section{Zadorozhnya L.V. (Kharkiv)}

The article is devoted to the description of the organization of training in a foreign language according to the method of rivalry / cooperation. The author investigated the possibilities of the practical application of such forms as cooperation and rivalry and their impact on the educational process. The relevance of this problem is due to the need for the search for new ways, methods, techniques for effective training of foreign students, the need to develop optimal technologies for the process of learning a foreign language by using cooperation and rivalry strategies; a lack of fundamental theoretical research and practical developments on the application of cooperation and rivalry in teaching foreign languages. The author studies examples of interactive games that students find most interesting and entertaining and shows various ways of organizing work in small groups. Among the most effective forms of pair and group work are intemal (external) circles, brainstorm, zigzag reading, opinion exchange, paired interviews . Technologies of rivalry and cooperation should be used in the educational process in a complementary manner. To success fully form the abilities of oral professional communication, it is necessary to systematically use the entire arsenal of funds and techniques that implement strategies for cooperation and rivalry. The author describes the impact of these methods on the educational process, namely the stimulation of personal, intellectual activity, development of cognitive processes, formation of competencies that the future specialist should have.

Key words: cooperation/rivalry, differentiated learning, foreign language, organization of foreign language teaching, teaching methods.

Задорожня Л.В. Організація навчання за методом співробітництва / суперництва на заняттях 3 іноземної мови. Стаття присвячена опису організації навчання іноземної мови за методом суперництва / співробітництва. Виявлено можливості практичного застосування таких методів, як співробітництво й суперництво, і їхній вплив на навчальний процес. Актуальність зазначеної проблеми обумовлена потребою в пошуку нових шляхів, способів, прийомів, методів ефективного навчання іноземних студентів, необхідністю розробки оптимальних технологій процесу навчання іноземної мови за допомогою задіяння стратегій співробітництва й суперництва; відсутністю фундаментальних теоретичних досліджень i практичних розробок щодо застосування співробітництва й суперництва в навчанні іноземної мови. Розглянуто приклади проведення найцікавіших для студентів інтерактивних ігор. Зазначено різні способи організації роботи

(C) Zadorozhny a L.V., 2021 
в малих групах. Найбільш ефективними $є$ такі форми парної і групової роботи: внутрішні (зовнішні) кола; мозковий штурм; читання зигзагом; обмін думками; парні інтерв'ю. Зроблено висновок про комплексне використання в навчальному процесі методу суперництва і співробітництва. Для успішного формування вмінь усного професійного спілкування потрібно систематично використовувати весь арсенал засобів і прийомів, що реалізують стратегії співробітництва й суперництва. Описано вплив представлених методів на навчальний процес, який полягає у стимулюванні особистісної інтелектуальної активності, розвитку пізнавальних процесів, у формуванні компетенцій, якими повинен володіти майбутній фахівець.

Ключові слова: диференційоване навчання, іноземна мова, методики навчання, організація навчання іноземної мови, співпраця / суперництво.

Задорожняя Л.В. Организация обучения по методу сотрудничества / соперничества на занятиях по иностранному языку. Статья посвящена описанию организации обучения иностранному языку по методу соперничества / сотрудничества. Выявлены возможности практического применения таких методов, как сотрудничество и соперничество, и их влияние на учебный процесс. Актуальность данной проблемы обусловлена потребностью в поиске новых путей, способов, приемов, методов эффективного обучения иностранных студентов, необходимостью разработки оптимальных те хнологий процесса обучения иностранному языку посредством задействования стратегий сотрудничества и соперничества; отсутствием фундаментальных теоретических исследований и практических разработок по применению сотрудничества и соперничества в обучении иностранному языку. Рассмотрены примеры проведения наиболее интересных студентам интерактивных игр. Указаны различные способы организации работы в малых группах. Наиболее эффективны такие формы парной и групповой работы: внутренние (внешние) круги; мозговой штурм; чтение зигзагом; обмен мнениями; парные интервью. Сделан вывод о комплексном использовании в учебном процессе метода соперничества и сотрудничества. Для успешного формирования умений устного профессионального общения необходимо систематически использовать весь арсенал средств и приемов, реализующих стратегии сотрудничества и соперничества. Описано влияние данных методов на учебный процесс, которое заключается в стимулировании личностной, интеллектуальной активности, развитии познавательных процессов, в формировании компетенций, которыми должен обладать будущий специалист.

Ключевые слова: дифференцированное обучение, иностранный язык, методики обучения, организация обучения иностранному языку, сотрудничество / соперничество .

Formulation of the problem in general. Teaching a foreign language is a complex multifaceted process that requires the regular and creative activity of a teacher. A modern teacher needs to know the 
latest methods of teaching a foreign language, special teaching techniques, and ways to optimally select one or another teaching method in accordance with the level of knowledge, needs, and interests of students. The teacher provides training in communication in a foreign language, offering students communicative situations that are as close as possible to real ones and creating students' need to speak, thereby forming professional communication among future specialists. To create students' communicative needs, the teacher offers motivesincentives, deliberately placing the participants in such conditions in which they will necessarily be active, for example, in a game, in a problem situation, in solving professional problems. However, even if all the necessary conditions for creating and deploying a situation of verbal communication are met, full-fledged and effective communication often does not occur. Teachers claim that this is due to the inability of students to listen to communication partners, maintain communication, and ask questions correctly and logically. This is explained by the insufficiently developed communicative ability of students, which manifests itself in the implementation of speech activity when the participants in communication are forced to formulate thoughts in a foreign language. The use of various strategies of professional communication allows implementing a variety of communicative intentions and overcoming these difficulties. Communication strategies are formed in interpersonal communication and are determined by the principles and goals of communicative interaction. In our opinion, the strategies of such interaction should include cooperation and rivalry. The implementation and success of any of these strategies depend on the purposeful activities of both the student and the teacher. We will focus on the strategies of cooperation and competition in the educational process and consider how you can organize and implement training based on them.

The topicality of the research is due to the need to find new ways, methods, techniques, methods of effective teaching of foreign students, the need to develop optimal technologies for the process of teaching a foreign language through the use of strategies of cooperation and rivalry; a lack of fundamental theoretical research and practical development on the use of cooperation and competition in teaching a foreign language.

The aim of the work is to describe the organization of teaching a foreign language by the method of rivalry/cooperation; to identify 
the possibilities of the practical application of such methods as cooperation and rivalry and their impact on the educational process.

Analysis of recent researches and publications. S. Averyanova insists on the obligatory use of the rivalry strategy in foreign language lessons. In her opinion, this helps students, as it motivates them for selfdevelopment, helps to improve speaking skills and capabilities [1]. N. Matskhonashvili also says about the benefits of the spirit of competition in teaching foreign languages. He writes that game techniques based on rivalry help to increase the motivation of students, which in turn increases their academic performance [2]. However, there is another point of view. K. Tomlinson, for example, has a definition of differentiated instruction. She believes that the very concept of differentiation implies that students are not competing with each other, but with themselves [5: 2]. And some researchers speak directly about the dangers of using rivalry in the classroom since competition leads to hostility and suppresses students. As an alternative, it is proposed to use training in cooperation [4]. Thus, an analysis of the literature on this issue has shown an absence of consensus among methodologists about the influence of training in competition on the motivation of students and the effectiveness of their training.

Presentation of the main material. The desire for communication is one of the leading motives prompting a person for joint practical activities. It is the joint practical activity of the teacher and the students that forms the basis of the strategy of cooperation in learning. Participants in communication achieve their goals by using various forms of communication: speaking, listening, reading, written communication, and performing a variety of exercises focused on the formation of both linguistic and communicative competences.

Game is one of the most accessible types of activity for students, a way of processing impressions received from the outside world. In the game, the peculiarities of thinking and imagination, emotionality, activity, developing the need for communication are clearly manifested. An interesting game increases the student's level of activity, and he can solve a more difficult problem than at a regular lesson. But this does not mean that all classes should take place in the form of a game.

Consider further examples of the most interesting interactive games for students. The following games provide for mastering the vocabulary of a studied topic and common words. "Grab-a-minute" is a game in which the student is given 1 minute to introduce a term written on an 
interactive map. It is necessary to provide additional information about this subject / term, its meaning, use, etc. The winner is the student who provides the most complete and coherent information about the subject or term indicated in the card. As a result of the game, students improve their quick response and critical thinking skills. "An-item-description" is a game in which you need to describe a word or phrase indicated on interactive maps without naming the root of the word or using gestures. In this case, other groups try to guess the word. During this game, the search for synonyms in English is activated. Direct communicative contact with the group has a positive effect on the relationship within the group. "Chain story" is a game of logic, a manifestation of imagination and individuality. The essence of the game is to continue the story of the previous student. This game forms the skills of quick response, logical thinking, increases attention, helps to develop memory.

Relevant discussion forms make students analyze their thoughts before voicing them because an obligatory element is not only speech but also an explanation of the course of their thoughts. In training based on cooperation/rivalry, we suggest using the game: "Roundtable" (collective game to solve a common problem); "Scientific debate" (educational dispute-dialogue, in which students are representatives of different directions and have to defend their opinions, the opposite of others'); "Competition in small groups" (a motivational game that encourages students to be active); "Brainstorm" (a game that develops critical thinking); "Situation" (A game that develops the ability to quickly react and fantasize); "Judicial sitting" (Playing with the distribution of roles and the search for constructive answers); "Training" (a form of training using various forms of work with a small group to improve skills in the process of simulating situations close to reality). An example would be the game "What? Where? When?". The audience is divided into two teams, which take turns sitting at the table. The game is played by analogy with the famous TV show. Each team receives an envelope with a question. The jury determines the correctness of the answers, calculates the number of points.

The constant conduct of interactive classes contributes to a significant improvement in communication skills, as a result of which the student's internal limitations disappear. In the process of communication, students learn to communicate with different people, 
express alternative opinions, make informed decisions, and participate in discussions.

The games considered make it possible to practically increase the amount of speaking practice at the lesson, turn out to be interesting for students, help to assimilate the material and use it in further studies, and perform didactic and developmental functions.

There are various ways to organize small group work. The most effective forms of pair and group work: internal (external) circles (inside / outside circles); brainstorming (brainstorm); jigsaw reading; exchange of views (think-pair-share); pair interviews and others.

One of the methods for teaching English is the project method as a way of developing creativity, cognitive activity, and independence. Projects can be subdivided into mono projects, collective, oral, specific, written, and Internet projects. Project work is a multi-layered approach to learning English, covering reading, listening, speaking and grammar. The project method contributes to the development of active independent thinking of students and orientates them towards joint research work. Project-based teaching is relevant in that it teaches students to cooperate, fosters such ethical values as mutual assistance and the ability to empathize, forms creativity, and activates students.

The use of collaborative learning methodology does not in any way imply a rejection of the traditional approach. All researchers of the problem of group learning conclude that this type of activity brings positive results only in combination with traditional methods. It seems appropriate to use group forms and methods of work in about $25 \%$ of the study time.

The recommendations discussed above are mainly focused on the implementation of the strategy of cooperation, but in the educational process, there is another strategy - the strategy of competition. We believe that this strategy should be used in foreign language classes, since it invariably leads to an increase in the quantity and quality of assimilation of speech material and, accordingly, helps to develop and improve the speech skills and abilities of students, to identify the individuality of the student and their speech abilities. The example is the normative speech of a foreign language teacher or the speech of a student who is fluent in a foreign language. The motive "Do the same, do better and more!" is the main driving force behind the selfdevelopment of any personality. 
The positive sides of learning in competition, in our opinion, is students' reliance on their knowledge; in cooperation - the help of a classmate who can suggest something, explain; discussing and finding that a joint solution is much more interesting than working alone; the need to use the target language during discussions, which serves as additional training.

Another advantage of group learning is the ability to implement a multi-level approach to teaching a foreign language. The teacher has the opportunity to provide students with different potential and abilities with multilevel assignments. At the same time, the so-called "weak" student will feel able to complete the task given to him or her, which will ultimately increase their motivation to study the subject. Group learning is based on the principles of social interaction, positive interdependence, personal accountability, everyone's equal participation. Social interaction of students has a positive effect on the psychological climate in the group as a whole: students receive qualitatively new social roles, which turns them from rivals into members of the same team. Group work contributes to the formation and development of such communication skills and abilities as listening and trusting a friend's actions, asking members of the same team questions, taking different opinions, leading a group, and providing feedback. All this ultimately forms the ability to work in a team.

The principle of positive interdependence is that the successful completion of work by an entire group depends on the results of the work of each of the members of that group. Positive dependency can be created by considering that members of the group must have something in common, for example, a common goal, reward, materials, distribution of roles, and tasks. It is important to draw the attention of all group members to the fact that success depends not only on the wellcoordinated work of the entire group as a whole but also on the personal contribution of each member.

Among the negative aspects of rivalry, one should note the deterioration of the quality of the task being performed due to haste (due to inattention); the emergence of an aggressively hostile attitude towards an opponent; an unpleasant feeling of tension and excitement while doing work.

Among the negative aspects of cooperation can be called the fact that not everyone in the group is equally responsible for doing the work; someone does more, and someone slows down the work of the 
group due to a low level of language proficiency or a lack of desire to work. Some students prefer to work independently and may be annoyed or distracted by other students. The very fact of having to work with another person can be stressful. An interesting fact is that the part of the students who claimed that the ideal condition for them would be independent work (without rivalry or cooperation), and the part who said that they felt the excitement and the desire to do better in competition when asked to choose between competition and cooperation preferred the latter.

After each stage, students were also asked to answer the question: which teaching method they considered more interesting and which was more useful for learning a foreign language. Benefit and interest were separated to exclude the possibility of choosing an easier or pleasant but less effective method. The groups participating in the experiment were already capable of reflection on the study of a foreign language, and some chose different methods in the categories "more interesting" and "more useful". Most of the students noted the work in collaboration as the most interesting and rewarding. Some of the trainees noted that for all-round development, it was worth alternating training in competition and in cooperation. Overall, collaborative learning was more successful. The students enthusiastically took up work, solved the emerging issues in the target language, they were satisfied and motivated for further interaction after completing the required tasks. Rivalry often caused conflicts; students were offended and refused to work in the future. Lagging students in most cases refused to participate in the competition at all giving up in advance. When learning in collaboration, most of the underperforming people got involved in the work. Considering that it was not possible to identify an obvious preponderance of the preferences of students or the difference in results, it seems most appropriate to use these methods alternately or to choose the preferred method depending on the characteristics of the group.

With the obvious positive aspects of learning in collaboration, it is necessary to note some difficulties associated with organizing group work. The most typical are the following: some students may behave too passively or, conversely, too aggressively; one or two students often take on the role of leaders and perform significant amounts of work, while the rest of the group takes a passive part in a joint endeavor; students can refrain from making independent decisions; not all ideas 
proposed in the group are taken into account. When organizing group work, you should pay attention to the following details: it is important to make sure that students have the knowledge and skills necessary to complete the group assignment; instructions should be as clear as possible; you must allow sufficient time to complete the assignment.

Conclusions. Collaborative / competitive learning is the use of small groups of learners in a real or virtual (distance learning) classroom. The solution of educational problems presupposes such an organization of the educational process in which all members of the group are interconnected and interdependent, and at the same time are quite independent in mastering the material and solving problems. In the process of social contacts between students, a community of people is created who possess certain knowledge and are ready to receive new knowledge in the process of communicating with each other, joint cognitive activity. Collaborative/competitive learning is collaborative exploration whereby learners work together, collectively constructing, producing new knowledge, rather than consuming off-theshelf knowledge. Independent educational activity of students is one of the principles of learning in cooperation/rivalry. The role of the teacher is changing. The teacher is a full participant in the educational process. In some cases, the teacher is involved by the trainees as a consultant or assistant. The main difficulty on the path to mastering a foreign language is a lack of oral practice of students at each lesson. The teaching methodology in cooperation/rivalry involves providing the necessary conditions for students to communicate with each other and with the teacher, and communication is carried out in a foreign language, which allows, as a result of systematic and purposeful work, significantly increasing the amount of oral speech practice at the lesson for each student.

For the successful formation of the skills of oral professional communication, it is necessary to systematically use the entire arsenal of means and techniques that implement the strategies of cooperation and rivalry. It is necessary to evaluate not only students' knowledge of various language constructions but also their ability to effectively use them in situations of professional communication.

Prospects for further research are in the investigation of ways to implement technologies of cooperation and rivalry in teaching foreign languages, in the creation, testing, experimental verification of the effectiveness of the technologies under consideration. 


\section{LITERATURE}

1. Аверьянова С.В. Коммуникативные стратегии при обучении устному деловому общению на занятиях по иностранному языку в высшей школе. Российский внешнеэкономический вестник. 2013. № 3. C. 80-86. URL: http://cyberleninka.ru/article/n/ko mmunikativnyestrategii-pri-obuchenii-ustnomu-de lovo muobscheniyu-na-zanyatiyah -poinostrannomu-yazyku-v-vysshey-shkole (дата звернення: 03.03.21).

2. Мацхонашвили Н.К. Об эффективности игровых заданий на практических занятиях по иностранным языкам в общей системе профессиональной подготовки бакалавров (из опыта работы со студентами, изучающими русский язык в Академии физического воспитания и спорта Грузии). $2008 . \quad$ URL: http://cyberlen in ka.ru/artic le/n/ob -effektivnosti-ig rov yh-zadaniy-naprakt icheskih -zanyatiy ahpo-inos tranny m-y azy ka m-v-obschey-s is te meprofescionalnoy-podgotovki (дата звернення: 10.03.21).

3. Современные методы и технологии преподавания иностранных языков: сб. науч. ст. / Чуваш. гос. пед. ун-т; отв. ред. Н.В. Кормилина, Н.Ю. Шугаева. Чебоксары: Чуваш. гос. пед. ун-т, 2019. 449 с.

4. Lynch J., Modgil C., Modgil S. Cultural Diversity And The Schools: Vol. 2: Prejudice, Polemic Or Progress? Routledge, 2006. 428 p.

5. Tomlinson C.A. Differentiate Instruction In Mixed-Ability Classrooms. Alexandria: Association for Supervision and Curriculum Development, 2001. 117 p.

\section{REFERENCES}

1. Averyanova, S.V. (2013). Kommunikativnye strategii pri obuchenii ustnomu delovomu obshcheniyu na zanyatiyah po inostrannomu yazy ku $\mathrm{v}$ vysshej shkole [Communicative strategies in teaching foreign language oral business communication in higher school]. Rossijskij vneshneekonomicheskij vestnik [Russian Foreign Economic Bulletin]. 3, pp. 80-86. Available at: http://cyberleninka.ru/article/n/ ko mmunikativnye-strategii-pri-obuchenii-ustno mu-de lovo muobscheniyuna-zanyatiyah-po-inostrannomu-yazyku-v-vysshey-shkole [Accessed 03 March 2021] [in Russian].

2. Mackhonashvili, N.K. (2008). Ob effektivnosti igrovyh zadanij na prakticheskih zanyatiyah po inostrannym yazykam $v$ obshchej sisteme professionalnoj podgotovki bakalavrov (iz opyta raboty so studentami, izuchayushchimi russkij yazyk $v$ Akademii fizichesko go vospitaniya i sporta Gruzii) [On the efficiency of play assignments during practical classes of foreign languages in the general system of bachelors' professional preparation (based on the experience of working with students who studied 
Russian at the Academy of physical training and sports of Georgia)]. Available at: http://cyberleninka.ru/article/n/ob-effektivnosti-igrovyhzadaniy-na-prakticheskih-zanyatiyahpo-inostrannym-yazy kam-v-obscheysisteme-profescionalnoy-podgotovki [Accessed 10 March 2021] [in Russian].

3. Kormilina, N.V. and Shugaeva, N.Yu . (Eds.). (2019). Sovremennye metody i tekhnologii prepodavaniya inostrannyh yazykov [Modern methods and technologies for teaching foreign languages]. Cheboksary: Chuvash State Pedagogical University [in Russian].

4. Lynch, J., Modgil, C. and Modgil S. (2006). Cultural Diversity and the Schools: Vol. 2: Prejudice, Polemic Or Progress? Routledge [in English].

5. Tomlinson, C.A. (2001). Differentiate Instruction in Mixed-Ability Classrooms. Alexandria: Association for Supervision and Curriculum Development [in English].

Задорожня Людмила Вікторівна, старший викладач кафедри мовної підго товки 2 Навчально-наукового інституту міжнародної освіти Харківського національного університету імені В.Н. Каразіна (61022, Харків, майдан Свободи, 4); e-mail: lludm8139@gmail.com; orcid: http://orcid.org/0000-0001-6607-3550.

Задорожняя Людмила Викторовна, старший преподаватель кафедры языковой подготовки 2 Учебно-научного института международного образования Харьковского национального университета имени В.Н. Каразина (61022, Харьков, площадь Свободы, 4); e-mail: lludm8139@gmail.com; orcid: http://orcid.org/0000-0001-6607-3550.

Liudmyla Zadorozhnya, Assistant Professor, Language Training Department 2, International Education Institute for Study and Research, V.N. Karazin Kharkiv National University (61022, Kharkiv, 4 Svoboda Square); e-mail: 1ludm8139@gmail.com; orcid: http://orcid.org/0000-00016607-3550. 